OPEN ACCESS

Edited by:

Ling Lu,

Nanjing Medical University, China

Reviewed by:

Zengli Guo,

University of North Carolina at Chapel

Hill, United States

Isabel Ishizuka

Genentech Inc., United States

*Correspondence:

Angus W. Thomson

thomsonaw@upmc.edu

Specialty section:

This article was submitted to

Cell Death and Survival,

a section of the journal

Frontiers in Cell and Developmental

Biology

Received: 11 February 2021

Accepted: 21 May 2021

Published: 15 June 2021

Citation:

Thomson AW, Sasaki K and

Ezzelarab MB (2021) Non-human Primate Regulatory T Cells and Their Assessment as Cellular Therapeutics in Preclinical Transplantation Models.

Front. Cell Dev. Biol. 9:666959.

doi: 10.3389/fcell.2021.666959

\section{Non-human Primate Regulatory T Cells and Their Assessment as Cellular Therapeutics in Preclinical Transplantation Models}

\author{
Angus W. Thomson ${ }^{1,2 *}$, Kazuki Sasaki ${ }^{1}$ and Mohamed B. Ezzelarab ${ }^{1}$ \\ ${ }^{1}$ Department of Surgery, Thomas E. Starzl Transplantation Institute, University of Pittsburgh School of Medicine, Pittsburgh, \\ PA, United States, ${ }^{2}$ Department of Immunology, University of Pittsburgh School of Medicine, Pittsburgh, PA, United States
}

Non-human primates (NHP) are an important resource for addressing key issues regarding the immunobiology of regulatory $\mathrm{T}$ cells (Treg), their in vivo manipulation and the translation of adoptive Treg therapy to clinical application. In addition to their phenotypic and functional characterization, particularly in cynomolgus and rhesus macaques, NHP Treg have been isolated and expanded successfully ex vivo. Their numbers can be enhanced in vivo by administration of IL-2 and other cytokines. Both polyclonal and donor antigen (Ag) alloreactive NHP Treg have been expanded ex vivo and their potential to improve long-term outcomes in organ transplantation assessed following their adoptive transfer in combination with various cytoreductive, immunosuppressive and "Treg permissive" agents. In addition, important insights have been gained into the in vivo fate/biodistribution, functional stability, replicative capacity and longevity of adoptively-transferred Treg in monkeys. We discuss current knowledge of NHP Treg immunobiology, methods for their in vivo expansion and functional validation, and results obtained testing their safety and efficacy in organ and pancreatic islet transplantation models. We compare and contrast results obtained in NHP and mice and also consider prospects for future, clinically relevant studies in NHP aimed at improved understanding of Treg biology, and innovative approaches to promote and evaluate their therapeutic potential.

Keywords: regulatory T cells, non-human primates, transplantation, cell therapy, immunobiology

\section{INTRODUCTION}

NHP are a valuable resource for translational research on innovative therapies with potential for clinical application. These include strategies to promote transplant tolerance without the toxicities and morbidities associated with immunosuppressive (IS) drugs that fail to induce clinical tolerance (Knechtle et al., 2019). Mouse models of tolerance induction are inadequate predictors of tolerance in both NHP and humans (Sachs, 2003). This reflects the fact that unlike the latter species, specific pathogen-free (spf) laboratory mice do not acquire heterologous immunity, i.e., virus-induced $\mathrm{T}$

Abbreviations: Ab, antibody; Ag, antigen; (a)APC, (artificial) antigen-presenting cell; ATG, anti-thymocyte globulin; Co-SB, co-stimulation blockade; Cy, cyclophosphamide; darTreg, donor antigen alloreactive regulatory T cells; IS, immunosuppression/immunosuppressive; NHP, non-human primate; PBMC, peripheral blood mononuclear cells; spf, specific pathogen free; Teff, T effector cell(s); TGF $\beta$, transforming growth factor $\beta$; Tmem, memory T cell(s); Treg, regulatory $\mathrm{T}$ cell(s). 
cell memory that constitutes a powerful barrier to tolerance induction (Adams et al., 2003). In addition, whereas MHC class II Ags that are key to induction of alloimmunity are absent from rodent vascular endothelium, they are expressed constitutively by these cells in large animals (Choo et al., 1997; Houser et al., 2004). Due to (i) similarities between NHP and human immune systems, (ii) cross-reactivity between drug targets in these species, (iii) the outbred nature of NHP, (iv) their natural exposure to environmental pathogens, and (v) their longevity compared with mice, NHP are important models for studying mechanisms underlying immune regulation and tolerance (Fitch et al., 2019). NHP also allow evaluation of the scalability and safety of innovative therapeutic strategies (e.g., monitoring and management of adverse events, such as potential infusion reactions and infectious complications) and associated techniques, e.g., leukapheresis in conjunction with cell therapy, that are not practiced in rodents.

NHP Treg phenotype and function resemble those of human Treg (Anderson et al., 2008; Haanstra et al., 2008). As in humans, testing of their efficacy is dependent on their isolation, massive expansion and product validation. The ability to assess the in vivo stability and migration of adoptively-transferred Treg is also an important translational aspect of studies of these cells in NHP and crucial for their assessment as cellular therapeutics.

\section{ISOLATION, PURIFICATION, EX VIVO EXPANSION AND VALIDATION OF NHP TREG}

Details of methods developed for isolation and purification of NHP Tregs from blood or tissues, and for expansion and testing of polyclonal, polyspecific or donor Ag-alloreactive (dar) NHP Treg are summarized in Table 1. Thus, ex vivo expansion of cynomolgus or rhesus Treg after immunomagnetic bead or/and flow sorting has been well-described in response to either polyclonal stimuli (Gansuvd et al., 2007; Anderson et al., 2008), allogeneic PBMC (Porter et al., 2007) or dendritic cells (DCs) (Moreau et al., 2008), artificial (a)APCs (Weiner et al., 2015; Zhang et al., 2015) or CD40L-stimulated allogeneic B cells (sBc) (Ezzelarab et al., 2020; Alonso-Guallart et al., 2021). Most recent attention has focused on expansion of alloreactive Tregs using various protocols. Thus, Alonso-Guallart et al. (2021) expanded highly suppressive cynomolgus polyspecific Tregs using a combination of CD40L-engineered B cells from 3 to 4 animals representative of diverse MHCs. The expanded Tregs expressed high levels of Foxp3 and Helios, a high incidence of Treg-specific demethylated region demethylation, and markedly suppressed naïve $\mathrm{T}$ cell responses in vitro. Importantly, these Tregs also expanded after cryopreservation, an important benefit allowing protocol flexibility. Specificity assays confirmed they were suppressive following activation by any APCs whose MHC expression was shared by the $\mathrm{CD} 40 \mathrm{~L}-\mathrm{sBc}$ used during their expansion, proving that they were polyspecific (AlonsoGuallart et al., 2021). Recently, Ezzelarab et al. (2020) also used $\mathrm{CD} 40 \mathrm{~L}-\mathrm{sBc}$ of donor origin to expand cynomolgus darTregs that were adoptively-transferred to transplant recipients.
Weiner et al. (2015) flow-sorted CD4 ${ }^{+} \mathrm{CD} 25^{h i}$ cells from baboon PBMC, followed by expansion with IL-2, anti-CD3 $\mathrm{Ab}$, aAPCs (transfected with human CD58, CD32, and CD80), and rapamycin, with weekly restimulation. Expanded Treg were cryopreserved for 2 months, after which they were thawed and cultured for $48 \mathrm{~h}$ with the same stimulating agents. The purified Treg were expanded $>10,000$-fold and exhibited excellent suppressive function. Cryopreservation reduced the cells' suppressive function without changing their phenotype, but increasing levels of reactivation post-thawing improved cell viability and function, with a shift toward greater Treg purity. Thus, both the phenotype and function of the Tregs were preserved or even enhanced by increasing levels of restimulation post-thawing, reinforcing the concept of banking expanded recipient Tregs.

\section{MIGRATORY PROPERTIES}

Treg migratory ability is considered key to their in vivo homing to lymphoid tissues and sites of inflammation considered critical locations of their immunosuppressive function. While Treg markers are expressed in either accepted or rejected NHP kidney allografts (Haanstra et al., 2007), Treg recruitment to the interstitium of the graft has been implicated in metastable kidney transplant tolerance in rhesus macaques (Torrealba et al., 2004). Numerous studies, including those in transplanted animals (Chen and Bromberg, 2006; Lamarche and Levings, 2018; Mempel and Marangoni, 2019) have shown that the expression of specific chemokine receptors, integrins and selectins is required for Treg activity in vivo (Qin et al., 2008; Zhang et al., 2009) and that maximal graft protection occurs when Tregs migrate to both the transplant and the draining lymphoid tissue. Thus, optimization of procedures for generation of highly suppressive NHP Treg needs to include evaluation of the expression of a range of chemokine receptors compatible with their in vivo migration to both the allograft and lymphoid tissues. Zhang et al. (2015) reported that ex vivo-expanded polyclonal cynomolgus Treg expressed high levels of CXCR3/low levels of CD62L and CCR7, consistent with their potential accumulation at sites of inflammation.

\section{IN VIVO MOBILIZATION AND DEPLETION}

The influence of cytokine and other biological agent administration on Treg in NHP has been investigated (Table 2). Thus, specific hematopoietic growth factors have been evaluated for their ability to selectively increase Treg in vivo, with potential to enhance their therapeutic efficacy, whereas Treg-selective depleting agents enable assessment of the dependency of tolerance-promoting protocols on these cells.

\section{IL-2}

Inoculation of low dose IL-2 $\left(10^{5}-5 \times 10^{6} \mathrm{IU} / \mathrm{m}^{2}\right)$ expands $\mathrm{CD}^{+}{ }^{+}$Foxp $^{+}$Tregs preferentially due to the cells' expression of the high affinity IL-2 receptor alpha chain (CD25) 
TABLE 1 | Timeline of reports of Treg isolation, expansion and suppressive activity in NHP species.

\begin{tabular}{|c|c|c|c|c|c|c|}
\hline Species & Treg selection (purity) & Cell yield & Expansion method & $\begin{array}{l}\text { Expansion } \\
\text { rate }\end{array}$ & Suppressive activity & Reference(s) \\
\hline $\begin{array}{l}\text { Rhesus } \\
\text { macaque }\end{array}$ & T cells from spleen & $\begin{array}{l}200 \times 10^{6} \text { cells per recipient } \\
\text { (splenectomized) }\end{array}$ & Donor splenocytes + anti-CD80/CD86; 13 days & 2-4-fold & $\begin{array}{l}\text { In vivo infusion } 13 \text { days post allogeneic } \\
\text { kidney transplant; donor-specific } \\
\text { inhibition of rejection }\end{array}$ & $\begin{array}{l}\text { Bashuda et al., } \\
2005\end{array}$ \\
\hline Rhesus & $\begin{array}{l}\text { MACS }(90 \%) \text { or FACS } \\
(98 \%) \text { CD } 4^{+} \text {CD } 25^{+}\end{array}$ & Not indicated & Anti-CD3/CD28 beads + IL-2; 4 weeks & $300-2,000$-fold & $\begin{array}{l}\text { Up to } 1: 8^{a} \text { ratio, suppression of } \\
\text { autologous PBMC proliferation }\end{array}$ & $\begin{array}{l}\text { Gansuvd et al., } \\
2007\end{array}$ \\
\hline Rhesus & $\begin{array}{l}\text { Anti-CD8 and anti-CD20 } \\
\text { Dynabeads, or CD4 }{ }^{+} \\
\text {MACS, followed by } \\
\text { anti-CD25 MACS (82\%) }\end{array}$ & $10 \%$ of $\mathrm{CD}^{+}{ }^{+} \mathrm{CD} 4^{+} \mathrm{T}$ cells & Fresh cells used; no expansion & $\mathrm{n} / \mathrm{a}$ & $\begin{array}{l}\text { Proliferation of Teff in response } \\
\text { anti-CD3 or irradiated PBMC } \\
\text { decreased at } 1: 1^{a} \text { ratio, however } \\
\text { variation between animals }\end{array}$ & $\begin{array}{l}\text { Haanstra et al., } \\
2008\end{array}$ \\
\hline Rhesus & $\begin{array}{l}\text { FACS CD4 } 4^{+} \mathrm{CD} 25^{\text {hi }} \text { or } \\
\mathrm{CD} 4^{+} \mathrm{CD} 25^{+} \mathrm{CD} 127^{-}\end{array}$ & $10^{5}$ cells $/ \mathrm{mL}$ blood & Anti-CD3/CD28 beads + IL-2; 4 weeks & Up to 450 -fold & $\begin{array}{l}\text { CFSE-MLR, up to } 1: 100^{a} \text { ratio; } \\
\text { suppression of alloreactive response by } \\
\text { responder-specific or third-party Treg }\end{array}$ & $\begin{array}{l}\text { Anderson et al., } \\
2008\end{array}$ \\
\hline Rhesus & MACS CD4+CD127-/10 & $\begin{array}{l}7 \% \text { of } \mathrm{CD} 4+/ 1.3 \% \text { of total } \\
\text { PBMC; } 3.7 \times 10^{4} \mathrm{cells} / \mathrm{ml} \\
\text { blood }\end{array}$ & $\begin{array}{l}\text { Immature Mo-DC+ } \mathrm{IL}^{-2} \mathrm{2}^{+} \mathrm{IL}-15 ; 14 \text { days, or } \\
10 \text { days followed by } 2 \text { days without } \mathrm{DC}\end{array}$ & No expansion & $\begin{array}{l}\text { Suppression up to } 1: 40^{a} \text { ratio; } \\
\text { donor-specific }\end{array}$ & $\begin{array}{l}\text { Zahorchak et al., } \\
2009\end{array}$ \\
\hline Rhesus & $\begin{array}{l}\text { FACS } \\
\text { CD4+ CD25- CD127-/lo } \\
\text { cells (> 80\%) }\end{array}$ & $>$ or $=10^{6}$ & $\begin{array}{l}\text { Stimulation with anti-CD3 and anti-CD28 } \\
\text { microbeads ( } 1 \text { cell: } 2 \text { beads) + IL-2 (2,000 } \\
\mathrm{U} / \mathrm{ml}) \pm \text { rapamycin }(1,000 \mathrm{nM}) ; \text { re-stimulation at } \\
7 \text { and } 14 \text { days; harvested on day } 21\end{array}$ & 210-760-fold & $\begin{array}{l}\text { Strong suppression of } \mathrm{CD} 4^{+} \text {and } \\
\mathrm{CD} 8^{+} \mathrm{T} \text { cell proliferation in CFSE-MLR }\end{array}$ & $\begin{array}{l}\text { Singh K. et al., } \\
2012\end{array}$ \\
\hline $\begin{array}{l}\text { Cynomolgus } \\
\text { macaque }\end{array}$ & $\begin{array}{l}\text { FACS CD4 } 4^{+} \\
\text {CD25 }^{+} \text {CD127- }^{-}(>98 \%)\end{array}$ & $0.4 \%$ of $\mathrm{PBMC}$ & Allo DC (BM-DC/Mo-DC) + IL-2; 7 days & 12-25-fold & $\begin{array}{l}\text { CFSE-MLR, } \\
\text { PBMC }^{+} \text {anti-CD3/CD28 }{ }^{+} \text {Treg: } 30 \% \\
\text { inhibition at } 1: 3^{a} \text { ratio. Treg suppressive } \\
\text { function stimulated by } \\
\text { BM-DC }>\text { Mo-DC }\end{array}$ & Moreau et al., 2008 \\
\hline $\begin{array}{l}\text { Cynomolgus } \\
\text { (MS model) }\end{array}$ & $\begin{array}{l}\text { MACS CD4+ CD25+ } \\
(>90 \%)\end{array}$ & $6.4 \%$ of $\mathrm{T}$ cells & Fresh cells used; no expansion & $\mathrm{n} / \mathrm{a}$ & $\begin{array}{l}\text { Proliferation to anti-CD3/CD28 or } \\
\text { CD3/CD46 stimulation impaired during } \\
\text { active MS }\end{array}$ & Ma et al., 2009 \\
\hline Cynomolgus & $\begin{array}{l}\text { FACS } \\
\text { CD } 4^{+} \mathrm{CD}_{25} 5^{\text {hi }} \mathrm{CD} 127^{-} \text {from } \\
\text { PBMC }\end{array}$ & $5 \%$ total $\mathrm{CD} 4^{+}$cells & $\begin{array}{l}\text { NHP-specific anti-CD2/3/28 microbeads (cell: } \\
\text { bead ratio 1:2), rhu IL-2 (1,000 U/ml) and rhu } \\
\text { TGF-b; } 5 \mathrm{ng} / \mathrm{mL} \text { ); } 20 \text { day culture }\end{array}$ & >80-fold & $\begin{array}{l}\text { Strong suppressive effect at ratios up to } \\
\text { 1:4 (Treg:Teff) on } \mathrm{CD} 4^{+} \text {and } \mathrm{CD} 8^{+} \mathrm{T} \\
\text { cell proliferation }\end{array}$ & Dons et al., 2013 \\
\hline Cynomolgus & $\begin{array}{l}\text { FACS } \\
\mathrm{CD}^{+} \mathrm{CD} 25^{+} \mathrm{CD} 127^{-} \\
(>95 \%)\end{array}$ & $\begin{array}{l}4.7(2-6.9) \% \text { of blood CD4 } \\
\text { cells }\end{array}$ & $\begin{array}{l}\text { Artificial (a)APCs (L32) loaded with anti-CD3 } \\
\text { ( } 1: 1 \text { ratio) for } 7-8 \text { days with IL-2 + rapamycin; } \\
\text { restimulation with aAPCs on days } 7 \text { and } 14 \\
\text { without rapamycin; harvested on day } 21\end{array}$ & 1,000 -fold & $\begin{array}{l}\text { Potent suppression of } \\
\text { anti-CD3/CD28-indiced CD4 and CD8 } \\
T \text { cell proliferation }\end{array}$ & $\begin{array}{l}\text { Guo et al., 2015; } \\
\text { Zhang et al., } 2015\end{array}$ \\
\hline Cynomolgus & $\begin{array}{l}\text { FACS } \\
\mathrm{CD} 44^{+} \mathrm{CD} 25^{h i} \mathrm{CD} 127^{10}\end{array}$ & $0.5-1 \%$ of total PBMC & $\begin{array}{l}\text { Donor Ag alloreactive Tregs stimulated with } \\
\text { donor CD4OL-activated B cells + IL-2; harvest } \\
\text { on day } 9 \text { and co-culture with aAPCs (L32 } \\
\text { cells) + IL-2 for } 2 \text { subsequent rounds of } 7 \text { days }\end{array}$ & 10,000-fold & $\begin{array}{l}\text { Strong suppression (> polyclonal Tregs) } \\
\text { of autologous T cell proliferation in MLR } \\
\text { in response to donor APCs. }\end{array}$ & $\begin{array}{l}\text { Ezzelarab et al., } \\
2020\end{array}$ \\
\hline Cynomolgus & $\begin{array}{l}\text { FACS } \\
\mathrm{CD} 4+\mathrm{CD} 8^{-} \mathrm{CD}_{25} 5^{\text {hi }} \mathrm{CD} 127^{-}\end{array}$ & $\begin{array}{l}\text { Top } 1 \% \mathrm{CD}_{2} 5^{+} \text {cells in the } \\
\mathrm{CD} 4^{+} \mathrm{CD} 8^{-} \mathrm{CD} 127^{-} \text {gate }\end{array}$ & $\begin{array}{l}\text { Polyspecific Tregs expanded with a panel of } \\
\text { CD40L-stimulated B cells (CD40L-sBc) }\end{array}$ & $\begin{array}{l}10,000 \text {-fold } \\
\text { after } 28 \text { days ( } 4 \\
\text { rounds) }\end{array}$ & $\begin{array}{l}\text { Expanded Tregs suppressive after } \\
\text { activation by any APCs whose MHC } \\
\text { was shared by CD4OL-SBc used } \\
\text { during expansion }\end{array}$ & $\begin{array}{l}\text { Alonso-Guallart } \\
\text { et al., } 2021\end{array}$ \\
\hline
\end{tabular}


(Zorn et al., 2006; Sakaguchi et al., 2008; Liao et al., 2013). Aoyama et al. (2012) reported that administration of low-dose IL-2 (1 million international units $/ \mathrm{m}^{2} \mathrm{BSA} /$ day) significantly expanded peripheral blood $\mathrm{CD}^{+}$and $\mathrm{CD} 8^{+}$Tregs in normal cynomolgus macaques, with restricted expansion of non-Tregs. The expanded Tregs were principally CD45RA ${ }^{-}$Foxp $3^{h i}$ activated Tregs, with strong immunosuppressive activity in vitro.

Exposure of Treg to high IL-2 concentrations during their expansion can render the cells sensitive to "cytokine withdrawalinduced death" (Larsen et al., 2017) following their adoptive transfer. This phenomenon could potentially be alleviated by systemic IL-2 administration. Thus, Furlan et al. (2020) found that, in non-transplanted monkeys, adding low dose IL-2 (1 million units $/ \mathrm{m}^{2} /$ day) to rapamycin in vivo (target trough level: $5-15 \mathrm{ng} / \mathrm{ml}$ ) promoted a logarithmic increase in the halflife/persistence of adoptively-transferred, autologous NHP Treg, in effect doubling the number of stable circulating Treg compared with Treg infusion in combination with rapamycin alone.

Yamada et al. (2015) examined the influence of systemic IL-2 on T cell alloreactivity and the maintenance of tolerance to MHC mis-matched kidney allografts induced in cynomolgus macaques via mixed hematopoietic cell chimerism. When given low doses of IL-2 $\left(0.6-3 \times 10^{6} \mathrm{IU} / \mathrm{m}^{2}\right)$, animals that had accepted their grafts for 1-10 years in the absence of IS rejected acutely, with reactivation/expansion of alloreactive effector memory $\mathrm{T}$ cells. After stopping IL-2 administration, graft rejection was reversed and normal renal function restored.

\section{Hematopoietic Growth Factors}

Kean et al. (2011) found that a small molecule antagonist of CXCR4- and CXCL12-mediated chemotaxis (AMD3100; Plerixafor) mobilized circulating lymphocytes in rhesus macaques, with significant increases in Tregs. $\mathrm{CD} 4{ }^{+} \mathrm{CD} 25^{h i} \mathrm{CD} 127^{l o} \mathrm{FoxP} 3{ }^{+}$Tregs were mobilized efficiently, with increases as great as fourfold in leukapheresis products when compared with G-CSF administration alone. Overall, the results indicated that AMD3100 could mobilize a T cell repertoire that might provide protection against GVHD, and thus be of potential benefit in allogeneic hematopoietic stem cell transplantation. Also, in rhesus macaques, Sasaki et al. (2020) observed that combining GM-CSF and G-CSF administration increased the incidence of Treg in both blood and leukapheresis products. In these studies, the mobilized Treg exhibited a similar range of transcription factors, surface markers and chemokine receptors to Treg in normal monkey peripheral blood Treg. Moreover, when the mobilized Treg were expanded ex vivo, they displayed similar capacity to inhibit autologous $\mathrm{CD} 4^{+}$and $\mathrm{CD} 8^{+}$ $\mathrm{T}$ cell proliferation.

\section{Depletion of Treg}

Intravenous injection of cynomolgus monkeys with two doses of an IL-2-diphtheria toxin fusion protein (denileukin diftitox; 8 or $18 \mu \mathrm{g} / \mathrm{kg}$ ) resulted in a rapid, but short- duration reduction in circulating resting Tregs $\left(\mathrm{CD} 4^{+} \mathrm{CD} 45 \mathrm{RA}^{+} \mathrm{Foxp}^{+}\right)$ accompanied by a transient elevation in activated Tregs $\left(\mathrm{CD} 4^{+} \mathrm{CD} 45 \mathrm{RA}^{-}\right.$Foxp $\left.3^{h i}\right)$, followed by their partial depletion (50-60\%) (Yamada et al., 2012a). Wang et al. (2016) 
TABLE 2 | Agents used to selectively enhance or deplete Tregs in NHP species.

\begin{tabular}{|c|c|c|c|c|}
\hline Agent & Species & Dosage & Reported effect & References \\
\hline \multicolumn{5}{|l|}{ Enhancing agents } \\
\hline IL-2 & Cynomolgus macaque & $10^{6} \mathrm{IU} / \mathrm{m}^{2} /$ day & $\begin{array}{l}\text { Increased peripheral blood CD4 and CD8 Tregs } \\
\text { (mainly CD45RA- Foxp3 }^{h i} \text { ) }\end{array}$ & Aoyama et al., 2012 \\
\hline IL-2 & Rhesus macaque & $\begin{array}{l}10^{6} \mathrm{U} / \mathrm{m}^{2} / \text { day in combination } \\
\text { with adoptively-transferred } \\
\text { autologous Treg and rapamycin }\end{array}$ & $\begin{array}{l}\text { Doubling of peripheral blood Treg compared } \\
\text { with Treg infusion and rapamycin alone; stable } \\
\text { expression of Treg gene transcripts }\end{array}$ & Furlan et al., 2020 \\
\hline IL-2 & Cynomolgus macaque & $0.6-3 \times 10^{6} \mathrm{IU} / \mathrm{m}^{2}$ & $\begin{array}{l}\text { Acute cellular rejection of tolerated renal } \\
\text { allografts 1-10 years post-transplant; } \\
\text { reactivation and expansion of alloreactive T } \\
\text { effector memory cells }\end{array}$ & Yamada et al., 2015 \\
\hline $\begin{array}{l}\text { AMD3100 (Plerixafor),-- } \\
\text { antagonist of CXCR4 and } \\
\text { CXCL12-mediated } \\
\text { chemotaxis }\end{array}$ & Rhesus macaque & 1 mg/kg (single dose) & $\begin{array}{l}\mathrm{CD}^{+} / \mathrm{CD} 25^{\text {hi }} \mathrm{CD} 127^{l o} \text { FoxP3 } \\
\text { efficiently using } \mathrm{AMD} 3100 \text {-containing regimens; } \\
\text { up to fourfold enrichment in leukapheresis } \\
\text { products compared with use of G-CSF alone }\end{array}$ & Kean et al., 2011 \\
\hline GM-CSF and G-CSF & Rhesus macaque & $\begin{array}{l}\text { GM-CSF (Leukine; } 10 \\
\mu \mathrm{g} / \mathrm{kg} / \text { day); G-CSF (Neupogen; } \\
10 \mu \mathrm{g} / \mathrm{kg} / \text { day) }\end{array}$ & $\begin{array}{l}\text { Significant elevation of Treg in peripheral blood } \\
\text { and leukapheresis products }\end{array}$ & Sasaki et al., 2020 \\
\hline \multicolumn{5}{|l|}{ Depleting agents } \\
\hline $\begin{array}{l}\text { IL-2-diphtheria toxin fusion } \\
\text { protein }\end{array}$ & Cynomolgus macaque & Two doses (8 or $18 \mu \mathrm{g} / \mathrm{kg}$ ) & $\begin{array}{l}\text { Rapid, but short-lived decrease in peripheral } \\
\text { blood resting Tregs }\left(\mathrm{CD} 4^{+} \text {CD45RA }{ }^{+} \text {Foxp3 }{ }^{+}\right) \\
\text {with a transient increase in activated Tregs } \\
\left(C D 4^{+} \text {CD45RA }{ }^{-} \text {Foxp3 } 3^{h i}\right) \text {, followed by their } \\
\text { depletion by50-60\% }\end{array}$ & Yamada et al., 2012b \\
\hline $\begin{array}{l}\text { Anti-human CCR4 } \\
\text { immunotoxin }\end{array}$ & Cynomolgus macaque & $\begin{array}{l}25 \mathrm{mg} / \mathrm{kg} \text { twice a day for four } \\
\text { consecutive days, } 6 \text { h apart }\end{array}$ & $\begin{array}{l}\text { 78-89\% CCR4 }{ }^{+} \text {Foxp3 }^{+} \text {Treg reduction in } \\
\text { peripheral blood for approx } 10 \text { days; } 89-96 \% \\
\text { CCR4 }^{+} \text {Foxp }^{+} \text {Treg depletion in lymph nodes }\end{array}$ & Wang et al., 2016 \\
\hline
\end{tabular}

G(M)-CSF, granulocyte (macrophage)-stimulating factor.

demonstrated that an anti-human CCR4 immunotoxin bound and depleted cynomolgus CCR4 ${ }^{+}$cells in vitro. In addition, they showed that the immunotoxin bound to the CCR4 ${ }^{+}$Foxp $^{+}$ monkey Tregs in vitro. In vivo studies carried out in two naive cynomolgus revealed $78-89 \%$ CCR $^{+}{ }^{+}$Foxp $3^{+}$Treg depletion in the peripheral blood that lasted about 10 days. In lymph nodes

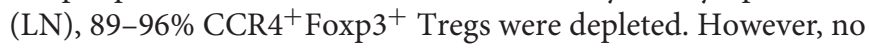
effect was observed on other immune cell populations, including other $\mathrm{CD}^{+}{ }^{+}$cells, $\mathrm{CD} 8^{+} \mathrm{T}$ cells, B cells and NK cells.

\section{INFLUENCE OF IS REGIMENS ON TREG IN ALLOGRAFT RECIPIENTS}

The existence of Treg in NHP kidney allografts during their rejection has been considered integral to the rejection response (Haanstra et al., 2007). On the other hand, specific induction of Tregs by donor Ags and intragraft enrichment of Tregs may be key to long-lasting tolerance in NHP induced by transient mixed chimerism (Hotta et al., 2016; Matsunami et al., 2019). Co-stimulation blockade (Co-SB) of the CD28 pathway is deleterious to Treg function, due likely to the importance of the complimentary CTLA4-CD80/86 pathway in Treg development and homeostasis. Thus, administration of CTLA4-Ig (Abatacept) decreases circulating Tregs in MHC-mismatched rhesus renal transplant recipients (Anderson et al., 2019). However, Poirier et al. (2015) found that a novel antagonistic pegylated anti-CD28 Fab' Ab fragment (FR104), together with low dose tacrolimus or rapamycin in a steroid-free treatment regimen, prevented acute allograft rejection and alloAb development, with accumulation of Helios ${ }^{-}$Tregs in the blood and graft. Blocking CD28 using a monovalent, non-activating single chain anti-CD28 Fv fragment linked to alpha-1 anti-trypsin (sc28AT) synergized with CNI in cynomolgus kidney and heart transplantation, increasing absolute numbers of peripheral Tregs (Zhang et al., 2018). Kim et al. (2017) found that a novel anti-human CD40L (CD154) domain $\mathrm{Ab}(\mathrm{dAb})$ that prolonged rhesus renal allograft survival without thromboembolism, and that synergized with conventional IS to more markedly control graft rejection, increased $\mathrm{CD} 4{ }^{+} \mathrm{CD} 25^{+}$Foxp $3^{+}$Treg frequency.

Ezzelarab et al. $(2013,2018)$ reported that infusion of donorderived DCreg 1 week before transplant prolonged rhesus renal allograft survival in combination with CD28 Co-SB and rapamycin and promoted maintenance of donor-reactive CD $4^{+}$CTLA $4^{h i}$ Tregs.

\section{TREG THERAPEUTIC PROTOCOLS IN TRANSPLANT RECIPIENTS}

Successful development of a therapeutic protocol based on adoptive transfer of Treg must address: (i) Treg efficacy and the number of cells required to achieve a therapeutic effect; (ii) stability of the suppressive phenotype; (iii) the Treg migratory pattern that assures their optimal regulatory function; (iv) the Ag specificity required for safe/effective control of rejection; (v) 
the impact of lymphocyte depletion/concomitant IS therapy on Treg function and durable control of rejection; (vi) conditions permissive to regulation of memory $\mathrm{T}$ cell responses. Several NHP studies (Table 3) have assessed feasibility, safety and therapeutic efficacy of adoptively-transferred, autologous Treg in transplant recipients. In a direct comparison of the persistence of transferred autologous vs. allogeneic Treg in peripheral blood of immunosuppressed, but not transplanted cynomolgus, we found that autologous Tregs survived much longer than the former
(Zhang et al., 2015), a property suggesting more durable potential efficacy of autologous Tregs.

\section{Renal Transplantation}

The earliest work (Bashuda et al., 2005) was conducted in rhesus macaques given MHC-mismatched renal allografts. Thus, autologous spleen-derived "suppressive T cells" (approx $10^{7 /} \mathrm{kg}$ ) that were rendered anergic by co-culture with donor alloAg together with anti-CD80/CD86 mAbs were infused

TABLE 3 | Assessment of adoptive Treg therapy in NHP transplant recipients.

\begin{tabular}{|c|c|c|c|c|}
\hline $\begin{array}{l}\text { Type of graft } \\
\text { (species) }\end{array}$ & IS therapy/conditioning & $\begin{array}{l}\text { Type of Tregs } \\
\text { (number/infusions) }\end{array}$ & Result & References \\
\hline Kidney (rhesus) $n=6$ & $\begin{array}{l}\text { Cyclosporine and post-transplant } \\
\text { cyclophosphamide }\end{array}$ & $\begin{array}{l}\text { Autologous splenocyte-derived } \\
\text { "suppressive T cells" (approx } \\
10^{7} / \mathrm{kg} \text { ) rendered anergic } \\
\text { following co-culture with donor } \\
\text { alloAg and anti-CD } 80 / 86 \text { mAbs } \\
\left(10^{2} \pm 67 \times 10^{6} \text { total on day }\right. \\
13 \text { post-transplant) }\end{array}$ & $\begin{array}{l}\text { Donor-specific tolerance in 50\% of graft } \\
\text { recipients }\end{array}$ & Bashuda et al., 2005 \\
\hline $\begin{array}{l}\text { Kidney (cynomolgus) } \\
n=4\end{array}$ & ATG and low dose rapamycin & $\begin{array}{l}\text { Expanded, donor Ag-specific, } \\
\text { host splenocyte-derived } \\
\text { CD4 }{ }^{+} \text {CD } 25^{+} \text {Treg ( } 14 \text { daily } \\
\text { infusions; } 10^{7} \text { per day) }\end{array}$ & $\begin{array}{l}\text { Graft MST prolonged from } 22 \text { to } \\
48.5 \text { days }\end{array}$ & Ma et al., 2011 \\
\hline $\begin{array}{l}\text { Kidney (cynomolgus) } \\
(n=5)\end{array}$ & $\begin{array}{l}\text { Non-myeloablative conditioning and } \\
\text { MHC-mismatched BMT. Renal } \\
\text { transplantation (from the same BMT } \\
\text { donor) conducted } 4 \text { months after } \\
\text { BMT, with no IS }\end{array}$ & $\begin{array}{l}\text { Expanded polyclonal } \\
\text { autologous Treg } \\
\text { (15-53 × } 10^{6} / \text { infusion) during } \\
\text { the } 1 \text { st week post-transplant } \\
\text { (days } 0,2,5,7 \text { ) and day }+50 \\
\text { (total dose: } 88-96 \times 10^{6} / \mathrm{kg} \text { ) }\end{array}$ & $\begin{array}{l}\text { Two of } 5 \text { evaluable recipients of } \\
\text { Treg + BMT displayed T cell chimerism } \\
\text { up to } 335 \text { days post-BMT. In one } \\
\text { long-term surviving animal, the delayed } \\
\text { kidney graft survived > } 294 \text { days } \\
\text { without IS, however, non-Treg BMT } \\
\text { recipients rejected their delayed kidney } \\
\text { grafts within 3-4 weeks }\end{array}$ & Duran-Struuck et al., 2017 \\
\hline $\begin{array}{l}\text { Heart (cynomolgus) } \\
n=5\end{array}$ & $\begin{array}{l}\text { ATG, tacrolimus, anti-IL-6R mAb } \\
\text { and tapered rapamycin } \\
\text { maintenance IS therapy }\end{array}$ & $\begin{array}{l}\text { Expanded polyclonal Tregs } \\
\text { (single or multiple doses (up to } \\
\text { a maximum cumulative cell } \\
\text { dose of } 1.87 \text { billion cells during } \\
\text { the early post-transplant period } \\
\text { (up to } 1 \text { month post-transplant) }\end{array}$ & $\begin{array}{l}\text { Inferior graft function with multiple } \\
\text { infusions; elevated incidences of T } \\
\text { effector memory cells, increased IFN } \gamma \\
\text { production by host CD8 }{ }^{+} \text {T cells, } \\
\text { enhanced levels of proinflammatory } \\
\text { cytokines and anti-donor alloAb }\end{array}$ & Ezzelarab et al., 2016 \\
\hline $\begin{array}{l}\text { Heart (cynomolgus) } \\
n=5\end{array}$ & $\begin{array}{l}\text { ATG, tacrolimus and anti-IL-6R with } \\
\text { tacrolimus conversion to rapamycin } \\
\text { at } 2 \text { weeks (early cell infusion within } \\
3 \text { weeks post-transplant); ATG and } \\
\text { tacrolimus with tacrolimus } \\
\text { conversion to rapamycin at } 2.5 \\
\text { weeks (delayed cell infusion, } 6-8 \\
\text { weeks post-transplant) }\end{array}$ & $\begin{array}{l}\text { Expanded donor Ag alloreactive } \\
\text { Tregs; } 20.5-120 \times 10^{6} / \mathrm{kg} \text { for } \\
\text { each of } 2-4 \text { infusions }\end{array}$ & $\begin{array}{l}\text { No prolongation of graft survival; loss of } \\
\text { regulatory signature and } \\
\text { proliferative/survival capacity by } \\
\text { transferred Tregs }\end{array}$ & Ezzelarab et al., 2020 \\
\hline $\begin{array}{l}\text { Pig pancreatic islets } \\
\text { (xeno; rhesus) } n=3\end{array}$ & $\begin{array}{l}\text { ATG, CVF, anti-CD154 mAb, and } \\
\text { rapamycin }\end{array}$ & $\begin{array}{l}\text { Intraportal infusion }(x 1 \text { or } \times 2) \text { of } \\
\text { expanded } \\
\text { CD4+CD25 }{ }^{\text {hi }} \text { CD127lo } \\
\text { autologous Tregs } \\
\left(1.87-62.0 \times 10^{6}\right) \text { following } \\
\text { ATG depletion }\end{array}$ & $\begin{array}{l}\text { Treg infusion associated with more } \\
\text { stable and durable normoglycemia }\end{array}$ & Shin et al., 2015 \\
\hline $\begin{array}{l}\text { Pig pancreatic islets } \\
\text { (xeno; rhesus) } n=2\end{array}$ & $\begin{array}{l}\text { ATG, CVF, anti-CD154 mAb and } \\
\text { rapamycin }\end{array}$ & As above (ref 65) & $\begin{array}{l}\text { Engrafted pig islets rejected by } \\
\text { activated T cells following withdrawal of } \\
\text { maintenance IS }\end{array}$ & Shin et al., 2016 \\
\hline $\begin{array}{l}\text { Pig skin graft (xeno; } \\
\text { baboon) } n=4\end{array}$ & $\begin{array}{l}\text { Splenectomy, TBI, ATG, TI, } \\
\text { rapamycin, CVF, } \\
\text { GalKO/huCD46/huCD47 } \\
\text { transgenic donor pig HSCs, } \\
\text { anti-CD4OLAb, methylprednisolone }\end{array}$ & $25 \times 10^{6} / \mathrm{kg}$ (8 infusions) & Prolonged donor skin graft acceptance & Stern et al., 2017 \\
\hline
\end{tabular}

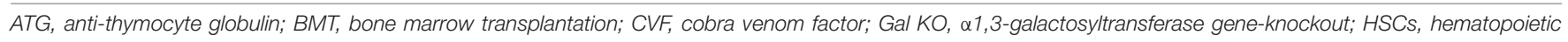
stem cells; hu, human; IS, immunosuppression; MST, mean/median graft survival time; TBI, total body irradiation; TI, thymic irradiation. 
once, 13 days post-transplant to splenectomized hosts that receiving brief cyclosporine and cyclophosphamide (Cy) treatment. Grafts survived long-term and donor-specific tolerance was achieved in $50 \%$ of recipients $(n=6)$, but not in controls, confirming the potential of a Treg therapy in NHP organ transplantation. These findings provided the basis for a clinical trial in living donor liver transplantation, in which splenic $\mathrm{T}$ cells rendered anergic to donor and administered 13 days post-transplant after $\mathrm{Cy}$, induced operational tolerance in 7/10 recipients (Todo et al., 2016). However, infusion of similarly generated Tregs 12 days posttransplant into living donor kidney transplant patients resulted in high rates of rejection upon subsequent IS drug withdrawal (Koyama et al., 2020).

$\mathrm{Ma}$ et al. (2011) reported that ex vivo-expanded autologous Treg prolonged renal transplant survival in ATG-treated cynomolgus monkeys. In this study, a much greater number of infusions (fourteen) of expanded, donor alloAg-specific, spleen-derived $\mathrm{CD} 4{ }^{+} \mathrm{CD} 25^{+}$Treg were infused $\left(10^{7}\right.$ per day). The infusions started at the time of transplantation (i.e., 1 day following a 3-day course of ATG) and were administered together with low-dose rapamycin for 14 days. Thus, kidney graft survival was prolonged significantly, but unlike in the aforementioned study, no grafts survived indefinitely.

Duran-Struuck et al. (2017) reported that recipient Treg co-transfer could enhance bone marrow (BM) engraftment/hematopoietic cell chimerism and prevent cynomolgus kidney allograft rejection. Eight monkeys were subjected to non-myeloablative conditioning and MHCmismatched BM transplantation (BMT), either with or without infusion of Treg. Transplantation (from the same BM donor) was undertaken 4 months post-BMT, in the absence of IS to evaluate robust, donor-specific tolerance. Five animals received ex vivo-expanded polyclonal autologous Treg during the first week post-transplant (days $0,2,5,7$ ) and also on day 50. Transient mixed chimerism, without significant $\mathrm{T}$ cell chimerism, was observed in those monkeys given BMT but no Treg $(n=3)$. By contrast, the 2 of 5 monkeys given Treg + BMT that could be evaluated showed multilineage (including $\mathrm{T}$ cell) chimerism up to 335 days after BMT. It was notable that, in the monkey that survived long-term, $>90 \%$ of donor $\mathrm{T}$ cells were found to be new thymic emigrants. In this monkey, the delayed (to 4 months) renal transplant was accepted for $>294$ days without IS therapy, whereas non-Treg BMT recipients rejected their delayed kidney grafts within 3-4 weeks. Early reactivation of cytomegalovirus (CMV) and anti-viral treatment was linked with early failure of chimerism, irrespective of Treg administration. Overall, these observations reveal that, without early CMV reactivation (and consequent BM-toxic anti-viral therapy), administration of host Treg can promote both prolonged multilineage chimerism and robust donor tolerance.

\section{Heart Transplantation}

Addressing the hypothesis that markedly reduced T cell numbers in graft recipients would favor the therapeutic efficacy of adoptively-transferred Tregs, Ezzelarab et al. (2016) infused ex vivo-expanded, polyclonal Treg into ATG-treated, MHCmismatched cynomolgus monkey heart transplant recipients before the homeostatic recovery of effector $\mathrm{T}$ cells. Tacrolimus, anti-IL-6R $\mathrm{mAb}$ and tapered rapamycin maintenance treatment was also administered. Infusion of Treg in either single or multiple doses during the early post-transplant period (up to a month post-transplant) during which time host $\mathrm{T}$ cells were markedly depleted, resulted in poorer heart graft function compared with non-Treg-infused controls. This was accompanied by an increased incidence of circulating effector memory $\mathrm{T}$ cells, elevated $\mathrm{IFN} \gamma$ production by $\mathrm{CD}^{+} \mathrm{T}$ cells, and enhanced levels of circulating proinflammatory cytokines and anti-donor alloAb. These observations suggest that Treg infusion early post-transplant period following lymphodepletion should be avoided in human clinical trials. Thus, despite marked but transient increases in circulating Treg relative to effector T cells and the use of so-called "Treg-friendly" agents, environmental conditions and host immune effector mechanisms that prevail under these conditions may negate the potential therapeutic efficacy of the infused transferred Treg.

In a more recent study (Ezzelarab et al., 2020), cynomolgus monkey autologous darTreg were expanded from flow-sorted, circulating Treg using activated donor B lymphocytes and infused after transplant into MHC-mismatched heart graft recipients. While the darTreg selectively suppressed proliferative responses of autologous $\mathrm{T}$ cells to donor alloAgs in vitro, their adoptive transfer post-transplant failed to prolong graft survival. Early (within 2 weeks post-transplant; under ATG, tacrolimus and antiIL-6R) or delayed (6-8 weeks post-transplant; under rapamycin) darTreg infusion resulted in a rapid reduction in transferred cells in the circulation. After early or delayed infusion, dye-labeled darTreg could be observed in lymphoid and non-lymphoid tissues and in the heart graft at low percentages $\left(<4 \% \mathrm{CD}^{+} \mathrm{T}\right.$ cells). Notably, the infused darTreg displayed reduced expression of Foxp3, CTLA4, Helios, the proliferative marker Ki67, and anti-apoptotic $\mathrm{Bcl} 2$, compared with pre-infusion darTreg and endogenous Treg.

\section{Comparison of Doses of darTreg Tested in NHP and Human Allograft Recipients}

Doses of darTreg tested in cynomolgus heart allograft recipients following lymphodepletion with ATG (Ezzelarab and Thomson, 2020) were similar to or greater than doses of autologous T cells rendered anergic to donor Ag and infused post-transplant to Cytreated, renal-allografted monkeys (Bashuda et al., 2005) and that induced donor-specific tolerance. However, they also resemble the single doses of similarly generated Tregs $\left(14-36 \times 10^{6} / \mathrm{kg}\right)$ infused 12 days post-transplant to living donor kidney transplant patients, including those given $\mathrm{Cy}$, that, by contrast, exhibited high rates of rejection upon subsequent IS drug withdrawal (Koyama et al., 2020). In other clinical studies of darTeg in living donor kidney transplantation, lower doses of darTreg have been targeted (i.e., $2 \times 10^{3}-2 \times 10^{6} / \mathrm{kg}$ or $0.5-10 \times 10^{6} / \mathrm{kg}$, respectively) in small numbers of patients at separate centers in 
the ONE Study (Sawitzki et al., 2020) in which overall safety of cell therapy and similar 1-year graft survival compared to a reference standard of care group have been reported. In human living donor liver transplantation, doses of 23.3-14.4 $\times 10^{6}$ $\mathrm{T}$ cells rendered anergic to donor and administered 13 days post-transplant after $\mathrm{Cy}$ induced operational tolerance in 7/10 recipients (Todo et al., 2016). A total of 300-500 × 10 6 darTreg have been targeted in a liver transplantation IS drug withdrawal study at UCSF (NCT02474199).

\section{TRACKING/MONITORING OF POLYCLONAL OR DARTREGS IN NORMAL NHP OR ORGAN ALLOGRAFT RECIPIENTS}

The in vivo persistence and migration of adoptively-transferred polyclonal Tregs to secondary lymphoid tissues documented in rodents have been confirmed by NHP studies that have determined the survival, migration, and function of exogenous Tregs. Detection of autologous or allogeneic Tregs infused into normal macaques has been accomplished by direct dye-labeling and subsequent tracking of the Tregs in blood, LNs and spleen at various times after their infusion (Singh et al., 2014; Zhang et al., 2015). Pharmacokinetic analysis of dye-labeled autologous Tregs has revealed an initial rapid period of elimination from the blood between day 0 and 3 post-infusion, after which the transferred Tregs persist at low levels for up to 3 weeks (Zhang et al., 2015). Staining for the cell proliferation marker Ki67 further demonstrates that label dilution as a result of cell proliferation does not contribute to the apparent disappearance of transferred Tregs from blood. Labeled autologous Tregs have been detected in LNs on day 1-2 post-infusion, however analysis on day 6 failed to demonstrate sustained persistence of infused Tregs in secondary lymphoid organs (Zhang et al., 2015).

Concurrent IS therapy markedly increases the survival of adoptively-transferred autologous Tregs in the peripheral blood and LNs. Labeled autologous Tregs persist longer in monkeys given rapamycin and in greater numbers compared to nonimmunosuppressed conditions at least 50 days post-infusion (Furlan et al., 2020). Low dose IL-2 together with rapamycin further prolongs the half-life of adoptively-transferred Tregs in NHPs, with detection of labeled cells in the periphery up to 84 days after infusion. These findings highlight a wide variability in the survival of infused Tregs under different conditions, including the use and type of IS, in addition to cell production methods, including cryopreservation.

\section{XENOTRANSPLANTATION}

Treg in xenotransplantation has been reviewed (Ezzelarab, 2018). Baboon Treg expanded in response to irradiated pig PBMC for potential use in pig-to-baboon xenotransplantation (Porter et al., 2007) proved strongly suppressive in vitro and donor-specific suppression was achieved. Huang et al. (2017) found that baboon autologous Tregs expanded by stimulation with pig PBMC could prevent porcine islet xenograft rejection in NOD-SCID IL-2r $\gamma^{-/-}$mice reconstituted with baboon PBMC. Prolonged xenograft survival to $>100$ days correlated with Treg engraftment and intragraft CD39 and Foxp3 gene expression. Shin et al. (2016) transplanted two diabetic rhesus with pancreatic islets isolated from wild-type miniature pigs with IS comprising ATG, cobra venom factor, anti-CD154 $\mathrm{mAb}$ and sirolimus. Expanded $\mathrm{CD} 4{ }^{+} \mathrm{CD} 25^{\text {hi }} \mathrm{CD} 127^{\text {lo }}$ autologous Tregs were infused during the peri-transplant period, however following withdrawal of maintenance IS, engrafted pig islets were rejected, indicating failure of tolerance induction by the autologous Tregs in this model.

\section{CONCLUSION AND FUTURE STUDIES}

NHP have the inherent advantage over rodent or humanized/primatized mouse models of closely resembling the human condition. Endogenous Treg in NHP can be increased or selectively depleted in vivo, and both polyclonal and darTreg have been expanded successfully ex vivo. In NHP kidney, heart and pancreatic islet transplantation, single or multiple infusions of autologous Treg have yielded results ranging from indefinite, IS-free graft survival to exacerbation of acute rejection, depending on the experimental model and IS regimen. In addition to valuable safety and graft outcome data that help guide clinical trial design, important insights have been gained into the biodistribution, stability and longevity of the transferred cells, and their influence on anti-donor immunity. These findings have drawn attention to the biological and logistical challenges encountered when transitioning testing of Treg therapeutic efficacy in inbred, spf mouse models, usually at very high/unphysiological Treg/effector cell ratios, to more clinically relevant NHP species. Exciting, newly evolving approaches to generation of stable, Ag-specific Tregs (Ferreira et al., 2019; Raffin et al., 2020), include gene editing of bulk T cells (Honaker et al., 2020) and production of CAR Tregs engineered to promote their Ag specificity and homing (MacDonald et al., 2016; Dawson et al., 2019; Hoeppli et al., 2019; Mohseni et al., 2020). Although there are no published reports of these developments as yet in NHP models, testing of such advances in NHP organ transplantation is keenly anticipated.

\section{AUTHOR CONTRIBUTIONS}

AT, KS, and ME participated in planning of the manuscript, literature searches, and in the writing of the mini-review. All authors contributed to the article and approved the submitted version.

\section{FUNDING}

This work was supported by the National Institutes of Health Non-human Primate Cooperative Study Group Grant U19 AI131453. 


\section{REFERENCES}

Adams, A. B., Pearson, T. C., and Larsen, C. P. (2003). Heterologous immunity: an overlooked barrier to tolerance. Immunol. Rev. 196, 147-160. doi: 10.1046/ j.1600-065x.2003.00082.x

Alonso-Guallart, P., Llore, N., Lopes, E., Kofman, S. B., Ho, S. H., Stern, J., et al. (2021). CD40L-stimulated B cells for ex-vivo expansion of polyspecific nonhuman primate regulatory $\mathrm{T}$ cells for translational studies. Clin. Exp. Immunol. 203, 480-492. doi: 10.1111/cei.13537

Anderson, A., Martens, C. L., Hendrix, R., Stempora, L. L., Miller, W. P., Hamby, K., et al. (2008). Expanded nonhuman primate Tregs exhibit a unique gene expression signature and potently downregulate alloimmune responses. Am. J. Transplant. 8, 2252-2264. doi: 10.1111/j.1600-6143.2008.02376.x

Anderson, D. J., Lo, D. J., Leopardi, F., Song, M., Strobert, E. A., Jenkins, J. B., et al. (2019). Corticosteroids and methotrexate as adjuvants to costimulation blockade in non-human primate renal transplantation. Clin. Transplant. 33:e13568.

Aoyama, A., Klarin, D., Yamada, Y., Boskovic, S., Nadazdin, O., Kawai, K., et al. (2012). Low-dose IL-2 for in vivo expansion of CD4+ and CD8+ regulatory T cells in nonhuman primates. Am. J. Transplant. 12, 2532-2537. doi: 10.1111/j. 1600-6143.2012.04133.x

Bashuda, H., Kimikawa, M., Seino, K., Kato, Y., Ono, F., Shimizu, A., et al. (2005). Renal allograft rejection is prevented by adoptive transfer of anergic $\mathrm{T}$ cells in nonhuman primates. J. Clin. Invest. 115, 1896-1902. doi: 10.1172/jci23743

Chen, D., and Bromberg, J. S. (2006). T regulatory cells and migration. Am. J. Transplant. 6, 1518-1523. doi: 10.1111/j.1600-6143.2006.01372.x

Choo, J. K., Seebach, J. D., Nickeleit, V., Shimizu, A., Lei, H., Sachs, D. H., et al. (1997). Species differences in the expression of major histocompatibility complex class II antigens on coronary artery endothelium: implications for cell-mediated xenoreactivity. Transplantation 64, 1315-1322. doi: 10.1097/ 00007890-199711150-00014

Dawson, N. A., Lamarche, C., Hoeppli, R. E., Bergqvist, P., Fung, V. C., McIver, E., et al. (2019). Systematic testing and specificity mapping of alloantigen-specific chimeric antigen receptors in regulatory T cells. JCI Insight 4:e123672.

Dons, E. M., Raimondi, G., Zhang, H., Zahorchak, A. F., Bhama, J. K., Lu, L., et al. (2013). Ex vivo-expanded cynomolgus macaque regulatory $\mathrm{T}$ cells are resistant to alemtuzumab-mediated cytotoxicity. Am. J. Transplant. 13, 2169-2178. doi: 10.1111/ajt.12248

Duran-Struuck, R., Sondermeijer, H. P., Buhler, L., Alonso-Guallart, P., Zitsman, J., Kato, Y., et al. (2017). Effect of ex vivo-expanded recipient regulatory T cells on hematopoietic chimerism and kidney allograft tolerance across MHC barriers in Cynomolgus Macaques. Transplantation 101, 274-283. doi: 10.1097/ tp.0000000000001559

Ezzelarab, M. B. (2018). Regulatory T cells from allo- to xenotransplantation: opportunities and challenges. Xenotransplantation 25:e12415. doi: 10.1111/xen. 12415

Ezzelarab, M. B., and Thomson, A. W. (2020). Plasmacytoid dendritic cells and the spontaneous acceptance of kidney allografts. Transplantation 104, 15-16. doi: $10.1097 /$ tp.0000000000002868

Ezzelarab, M. B., Lu, L., Shufesky, W. F., Morelli, A. E., and Thomson, A. W. (2018). Donor-derived regulatory dendritic cell infusion maintains donor-reactive CD4(+)CTLA4(hi) $\mathrm{T}$ cells in non-human primate renal allograft recipients treated with CD28 co-stimulation blockade. Front. Immunol. 9:250.

Ezzelarab, M. B., Zahorchak, A. F., Lu, L., Morelli, A. E., Chalasani, G., Demetris, A. J., et al. (2013). Regulatory dendritic cell infusion prolongs kidney allograft survival in nonhuman primates. Am. J. Transplant. 13, 1989-2005. doi: 10. 1111/ajt.12310

Ezzelarab, M. B., Zhang, H., Guo, H., Lu, L., Zahorchak, A. F., Wiseman, R. W., et al. (2016). Regulatory T cell infusion can enhance memory $T$ cell and alloantibody responses in lymphodepleted nonhuman primate heart allograft recipients. Am. J. Transplant. 16, 1999-2015. doi: 10.1111/ajt.13685

Ezzelarab, M. E., Zhang, H., Sasaki, K., Lu, L., Zahorchak, A. F., Van der Windt, D., et al. (2020). Ex vivo expanded donor alloreactive regulatory $\mathrm{T}$ cells lose immunoregulatory, proliferation and anti-apoptotic markers after infusion into ATG-lymphodepleted, nonhuman primate heart allograft recipients. Transplantation doi: 10.1097/TP.0000000000003617 Online ahead of print.
Ferreira, L. M. R., Muller, Y. D., Bluestone, J. A., and Tang, Q. (2019). Nextgeneration regulatory T cell therapy. Nat. Rev. Drug Discov. 18, 749-769. doi: 10.1038/s41573-019-0041-4

Fitch, Z., Schmitz, R., Kwun, J., Hering, B., Madsen, J., and Knechtle, S. J. (2019). Transplant research in nonhuman primates to evaluate clinically relevant immune strategies in organ transplantation. Transplant. Rev. 33, 115-129. doi: 10.1016/j.trre.2019.03.002

Furlan, S. N., Singh, K., Lopez, C., Tkachev, V., Hunt, D. J., Hibbard, J., et al. (2020). IL-2 enhances ex vivo-expanded regulatory T-cell persistence after adoptive transfer. Blood Adv. 4, 1594-1605. doi: 10.1182/bloodadvances. 201900 1248

Gansuvd, B., Asiedu, C. K., Goodwin, J., Jargal, U., Deckard, L. A., Andrades, P., et al. (2007). Expansion of CD4+CD25+ suppressive regulatory T cells from rhesus macaque peripheral blood by FN18/antihuman CD28-coated Dynal beads. Hum. Immunol. 68, 478-490. doi: 10.1016/j.humimm.2007. 02.011

Guo, H., Zhang, H., Lu, L., Ezzelarab, M. B., and Thomson, A. W. (2015). Generation, cryopreservation, function and in vivo persistence of ex vivo expanded cynomolgus monkey regulatory T cells. Cell. Immunol. 295, 19-28. doi: 10.1016/j.cellimm.2015.02.006

Haanstra, K. G., van der Maas, M. J., t Hart, B. A., and Jonker, M. (2008). Characterization of naturally occurring CD4+CD25+ regulatory $\mathrm{T}$ cells in rhesus monkeys. Transplantation 85, 1185-1192. doi: 10.1097/tp. 0b013e31816b15b9

Haanstra, K. G., Wubben, J. A., Korevaar, S. S., Kondova, I., Baan, C. C., and Jonker, M. (2007). Expression patterns of regulatory T-cell markers in accepted and rejected nonhuman primate kidney allografts. Am. J. Transplant. 7, 2236-2246. doi: 10.1111/j.1600-6143.2007.01917.x

Hoeppli, R. E., MacDonald, K. N., Leclair, P., Fung, V. C. W., Mojibian, M., Gillies, J., et al. (2019). Tailoring the homing capacity of human Tregs for directed migration to sites of Th1-inflammation or intestinal regions. Am. J. Transplant. 19, 62-76. doi: 10.1111/ajt.14936

Honaker, Y., Hubbard, N., Xiang, Y., Fisher, L., Hagin, D., Sommer, K., et al. (2020). Gene editing to induce FOXP3 expression in human CD4(+) T cells leads to a stable regulatory phenotype and function. Sci. Transl. Med. 12:eaay6422. doi: 10.1126/scitranslmed.aay6422

Hotta, K., Aoyama, A., Oura, T., Yamada, Y., Tonsho, M., Huh, K. H., et al. (2016). Induced regulatory $\mathrm{T}$ cells in allograft tolerance via transient mixed chimerism. JCI Insight 1:e86419.

Houser, S. L., Benjamin, L. C., Wain, J. C., Madsen, J. C., and Allan, J. S. (2004). Constitutive expression of major histocompatibility complex class II antigens in pulmonary epithelium and endothelium varies among different species. Transplantation 77, 605-607. doi: 10.1097/01.tp.0000114285.633 13.e7

Huang, D., Wang, Y., Hawthorne, W. J., Hu, M., Hawkes, J., Burns, H., et al. (2017). Ex vivo-expanded baboon CD39 + regulatory T cells prevent rejection of porcine islet xenografts in NOD-SCID IL-2 $\mathrm{r} \gamma^{-/-}$mice reconstituted with baboon peripheral blood mononuclear cells. Xenotransplantation 24:e12344. doi: 10.1111/xen.12344

Kean, L. S., Sen, S., Onabajo, O., Singh, K., Robertson, J., Stempora, L., et al. (2011). Significant mobilization of both conventional and regulatory T cells with AMD3100. Blood 118, 6580-6590. doi: 10.1182/blood-2011-06-35 9331

Kim, S. C., Wakwe, W., Higginbotham, L. B., Mathews, D. V., Breeden, C. P., Stephenson, A. C., et al. (2017). Fc-Silent Anti-CD154 domain antibody effectively prevents nonhuman primate renal allograft rejection. Am. J. Transplant. 17, 1182-1192. doi: 10.1111/ajt.14197

Knechtle, S. J., Shaw, J. M., Hering, B. J., Kraemer, K., and Madsen, J. C. (2019). Translational impact of NIH-funded nonhuman primate research in transplantation. Sci. Transl. Med. 11:aau0143.

Koyama, I., Bashuda, H., Uchida, K., Seino, K. I., Habu, S., Nakajima, I., et al. (2020). A clinical trial with adoptive transfer of ex vivo-induced, donorspecific immune-regulatory cells in kidney transplantation-a second report. Transplantation 104, 2415-2423. doi: 10.1097/tp.0000000000003149

Lamarche, C., and Levings, M. K. (2018). Guiding regulatory T cells to the allograft. Curr. Opin. Organ. Transplant. 23, 106-113. doi: 10.1097/mot. 0000000000000483 
Larsen, S. E., Voss, K., Laing, E. D., and Snow, A. L. (2017). Differential cytokine withdrawal-induced death sensitivity of effector $\mathrm{T}$ cells derived from distinct human CD8(+) memory subsets. Cell Death Discov. 3:17031.

Li, M., Eckl, J., Abicht, J.-M., Mayr, T., Reichart, B., Schendel, D. J., et al. (2018). Induction of porcine-specific regulatory $\mathrm{T}$ cells with high specificity and expression of IL-10 and TGF- ${ }^{\beta} 1$ using baboon-derived tolerogenic dendritic cells. Xenotransplantation 25:e12355. doi: 10.1111/xen.12355

Liao, W., Lin, J. X., and Leonard, W. J. (2013). Interleukin-2 at the crossroads of effector responses, tolerance, and immunotherapy. Immunity 38, 13-25. doi: 10.1016/j.immuni.2013.01.004

Ma, A., Qi, S., Song, L., Hu, Y., Dun, H., Massicotte, E., et al. (2011). Adoptive transfer of $\mathrm{CD} 4+\mathrm{CD} 25+$ regulatory cells combined with low-dose sirolimus and anti-thymocyte globulin delays acute rejection of renal allografts in Cynomolgus monkeys. Int. Immunopharmacol. 11, 618-629. doi: 10.1016/j. intimp.2010.11.001

Ma, A., Xiong, Z., Hu, Y., Qi, S., Song, L., Dun, H., et al. (2009). Dysfunction of IL-10-producing type 1 regulatory $\mathrm{T}$ cells and $\mathrm{CD} 4(+) \mathrm{CD} 25(+)$ regulatory $\mathrm{T}$ cells in a mimic model of human multiple sclerosis in Cynomolgus monkeys. Int. Immunopharmacol. 9, 599-608. doi: 10.1016/j.intimp.2009. 01.034

MacDonald, K. G., Hoeppli, R. E., Huang, Q., Gillies, J., Luciani, D. S., Orban, P. C., et al. (2016). Alloantigen-specific regulatory T cells generated with a chimeric antigen receptor. J. Clin. Invest. 126, 1413-1424. doi: 10.1172/jci8 2771

Matsunami, M., Rosales, I. A., Adam, B. A., Oura, T., Mengel, M., Smith, R. N., et al. (2019). Long-term kinetics of intragraft gene signatures in renal allograft tolerance induced by transient mixed chimerism. Transplantation 103:e334. doi: $10.1097 /$ tp.0000000000002911

Mempel, T. R., and Marangoni, F. (2019). Guidance factors orchestrating regulatory $\mathrm{T}$ cell positioning in tissues during development, homeostasis, and response. Immunol. Rev. 289, 129-141. doi: 10.1111/imr. 12761

Mohseni, Y. R., Tung, S. L., Dudreuilh, C., Lechler, R. I., Fruhwirth, G. O., and Lombardi, G. (2020). The future of regulatory T cell therapy: promises and challenges of implementing CAR technology. Front. Immunol. 11:1608.

Moreau, A., Chiffoleau, E., Beriou, G., Deschamps, J. Y., Heslan, M., AshtonChess, J., et al. (2008). Superiority of bone marrow-derived dendritic cells over monocyte-derived ones for the expansion of regulatory $\mathrm{T}$ cells in the macaque. Transplantation 85, 1351-1356. doi: 10.1097/tp.0b013e31816f22d6

Poirier, N., Dilek, N., Mary, C., Ville, S., Coulon, F., Branchereau, J., et al. (2015). FR104, an antagonist anti-CD28 monovalent fab' antibody, prevents alloimmunization and allows calcineurin inhibitor minimization in nonhuman primate renal allograft. Am. J. Transplant. 15, 88-100. doi: 10.1111/ajt.12964

Porter, C. M., Horvath-Arcidiacono, J. A., Singh, A. K., Horvath, K. A., Bloom, E. T., and Mohiuddin, M. M. (2007). Characterization and expansion of baboon $\mathrm{CD} 4+\mathrm{CD} 25+$ Treg cells for potential use in a non-human primate xenotransplantation model. Xenotransplantation 14, 298-308. doi: 10.1111/j. 1399-3089.2007.00416.x

Qin, S., Sui, Y., Soloff, A. C., Junecko, B. A., Kirschner, D. E., Murphey-Corb, M. A., et al. (2008). Chemokine and cytokine mediated loss of regulatory T cells in lymph nodes during pathogenic simian immunodeficiency virus infection. J. Immunol. 180, 5530-5536. doi: 10.4049/jimmunol.180.8.5530

Raffin, C., Vo, L. T., and Bluestone, J. A. (2020). Treg cell-based therapies: challenges and perspectives. Nat. Rev. Immunol. 20, 158-172. doi: 10.1038/ s41577-019-0232-6

Sachs, D. H. (2003). Tolerance: of mice and men. J. Clin. Invest. 111, 1819-1821. doi: $10.1172 /$ jci18926

Sakaguchi, S., Yamaguchi, T., Nomura, T., and Ono, M. (2008). Regulatory T cells and immune tolerance. Cell 133, 775-787. doi: 10.1016/j.cell.2008.05.009

Sasaki, K., Wang, Y. C., Lu, L., Hughes, J., Vujevich, V., Thomson, A. W., et al. (2020). Combined GM-CSF and G-CSF administration mobilizes CD4(+) CD25(hi) Foxp3(hi) Treg in leukapheresis products of rhesus monkeys. Am. J. Transplant. 20, 1691-1702. doi: 10.1111/ajt.15761

Sawitzki, B., Harden, P. N., Reinke, P., Moreau, A., Hutchinson, J. A., Game, D. S., et al. (2020). Regulatory cell therapy in kidney transplantation (The ONE Study): a harmonised design and analysis of seven non-randomised, single-arm, phase 1/2A trials. Lancet 395, 1627-1639.
Shin, J. S., Kim, J. M., Kim, J. S., Min, B. H., Kim, Y. H., Kim, H. J., et al. (2015). Long-term control of diabetes in immunosuppressed nonhuman primates (NHP) by the transplantation of adult porcine islets. Am. J. Transplant. 15, 2837-2850. doi: 10.1111/ajt.13345

Shin, J. S., Min, B. H., Kim, J. M., Kim, J. S., Yoon, I. H., Kim, H. J., et al. (2016). Failure of transplantation tolerance induction by autologous regulatory $\mathrm{T}$ cells in the pig-to-non-human primate islet xenotransplantation model. Xenotransplantation 23, 300-309. doi: 10.1111/xen. 12246

Singh, A. K., Seavey, C. N., Horvath, K. A., and Mohiuddin, M. M. (2012). Ex-vivo expanded baboon CD4+ CD25 Hi Treg cells suppress baboon anti-pig T and B cell immune response. Xenotransplantation 19, 102-111. doi: 10.1111/j.13993089.2012.00697.x

Singh, K., Kozyr, N., Stempora, L., Kirk, A. D., Larsen, C. P., Blazar, B. R., et al. (2012). Regulatory T cells exhibit decreased proliferation but enhanced suppression after pulsing with sirolimus. Am. J. Transplant. 12, 1441-1457. doi: 10.1111/j.1600-6143.2011.03963.x

Singh, K., Stempora, L., Harvey, R. D., Kirk, A. D., Larsen, C. P., Blazar, B. R., et al. (2014). Superiority of rapamycin over tacrolimus in preserving nonhuman primate Treg half-life and phenotype after adoptive transfer. Am. J. Transplant. 14, 2691-2703. doi: 10.1111/ajt.12934

Stern, J., Kofman, S. B., Alonso-Guallart, P., Berglund, E., Danton, M., Weiner, J., et al. (2017). Autologous expanded Tregs and Porcine hematopoietic cells to prolong xenogeneic pig skin graft acceptance in baboons. Am. J. Transplant. 17, 522-528.

Todo, S., Yamashita, K., Goto, R., Zaitsu, M., Nagatsu, A., Oura, T., et al. (2016). A pilot study of operational tolerance with a regulatory T-cell-based cell therapy in living donor liver transplantation. Hepatology 64, 632-643. doi: 10.1002/hep. 28459

Torrealba, J. R., Katayama, M., Fechner, J. H., Jankowska-Gan, E., Kusaka, S., Xu, Q., et al. (2004). Metastable tolerance to rhesus monkey renal transplants is correlated with allograft TGF-beta $1+\mathrm{CD} 4+\mathrm{T}$ regulatory cell infiltrates. J. Immunol. 172, 5753-5764. doi: 10.4049/jimmunol.172.9. 5753

Wang, Z., Pratts, S. G., Zhang, H., Spencer, P. J., Yu, R., Tonsho, M., et al. (2016). Treg depletion in non-human primates using a novel diphtheria toxin-based anti-human CCR4 immunotoxin. Mol. Oncol. 10, 553-565. doi: 10.1016/j. molonc.2015.11.008

Weiner, J., Duran-Struuck, R., Zitsman, J., Buhler, L., Sondermeijer, H., McMurchy, A. N., et al. (2015). Restimulation after Cryopreservation and thawing preserves the phenotype and function of expanded baboon regulatory T cells. Transplant. Direct 1, 1-7. doi: 10.1097/txd.00000000000 00511

Yamada, Y., Aoyama, A., Tocco, G., Boskovic, S., Nadazdin, O., Alessandrini, A., et al. (2012a). Differential effects of denileukin diftitox IL-2 immunotoxin on NK and regulatory T cells in nonhuman primates. J. Immunol. 188, 6063-6070. doi: 10.4049/jimmunol.1200656

Yamada, Y., Boskovic, S., Aoyama, A., Murakami, T., Putheti, P., Smith, R. N., et al. (2012b). Overcoming memory T-cell responses for induction of delayed tolerance in nonhuman primates. Am. J. Transplant. 12,330-340. doi: 10.1111/ j.1600-6143.2011.03795.x

Yamada, Y., Nadazdin, O., Boskovic, S., Lee, S., Zorn, E., Smith, R. N., et al. (2015). Repeated injections of IL-2 break renal allograft tolerance induced via mixed hematopoietic Chimerism in monkeys. Am. J. Transplant. 15, 3055-3066. doi: 10.1111/ajt.13382

Zahorchak, A. F., Raimondi, G., and Thomson, A. W. (2009). Rhesus monkey immature monocyte-derived dendritic cells generate alloantigenspecific regulatory $\mathrm{T}$ cells from circulating $\mathrm{CD} 4+\mathrm{CD} 127-/ \mathrm{lo} \mathrm{T}$ cells. Transplantation 88, 1057-1064. doi: 10.1097/tp.0b013e3181ba $6 \mathrm{~b} 1 \mathrm{f}$

Zhang, H., Guo, H., Lu, L., Zahorchak, A. F., Wiseman, R. W., Raimondi, G., et al. (2015). Sequential monitoring and stability of ex vivo-expanded autologous and nonautologous regulatory $\mathrm{T}$ cells following infusion in nonhuman primates. Am. J. Transplant. 15, 1253-1266. doi: 10.1111/ajt. 13113

Zhang, N., Schroppel, B., Lal, G., Jakubzick, C., Mao, X., Chen, D., et al. (2009). Regulatory $\mathrm{T}$ cells sequentially migrate from inflamed tissues to draining lymph 
nodes to suppress the alloimmune response. Immunity 30, 458-469. doi: 10. 1016/j.immuni.2008.12.022

Zhang, T., Azimzadeh, A. M., Sun, W., O’Neill, N. A., Sievert, E., Bergbower, E., et al. (2018). Selective CD28 inhibition modulates alloimmunity and cardiac allograft vasculopathy in Anti-CD154-treated monkeys. Transplantation 102, e90-e100.

Zorn, E., Nelson, E. A., Mohseni, M., Porcheray, F., Kim, H., Litsa, D., et al. (2006). IL-2 regulates FOXP3 expression in human CD4+CD25+ regulatory T cells through a STAT-dependent mechanism and induces the expansion of these cells in vivo. Blood 108, 1571-1579. doi: 10.1182/blood-2006-02-004747
Conflict of Interest: The authors declare that the research was conducted in the absence of any commercial or financial relationships that could be construed as a potential conflict of interest.

Copyright ( 2021 Thomson, Sasaki and Ezzelarab. This is an open-access article distributed under the terms of the Creative Commons Attribution License (CC BY). The use, distribution or reproduction in other forums is permitted, provided the original author(s) and the copyright owner(s) are credited and that the original publication in this journal is cited, in accordance with accepted academic practice. No use, distribution or reproduction is permitted which does not comply with these terms. 